\title{
PET imaging of hypoxia using [F-18]HX4: a phase I trial
}

Citation for published version (APA):

van Loon, J., Janssen, M. H. M., Ollers, M., Aerts, H. J. W. L., Dubois, L., Hochstenbag, M., Dingemans, A-M. C., Lalisang, R., Brans, B., Windhorst, B., van Dongen, G. A. M. S., Kolb, H., Zhang, J., De Ruysscher, D., \& Lambin, P. (2010). PET imaging of hypoxia using [F-18]HX4: a phase I trial. European Journal of Nuclear Medicine and Molecular Imaging, 37(9), 1663-1668. https://doi.org/10.1007/s00259010-1437-x

Document status and date:

Published: 01/08/2010

DOI:

10.1007/s00259-010-1437-x

Document Version:

Publisher's PDF, also known as Version of record

Document license:

Taverne

Please check the document version of this publication:

- A submitted manuscript is the version of the article upon submission and before peer-review. There can be important differences between the submitted version and the official published version of record.

People interested in the research are advised to contact the author for the final version of the publication, or visit the DOI to the publisher's website.

- The final author version and the galley proof are versions of the publication after peer review.

- The final published version features the final layout of the paper including the volume, issue and page numbers.

Link to publication

\footnotetext{
General rights rights.

- You may freely distribute the URL identifying the publication in the public portal. please follow below link for the End User Agreement:

www.umlib.nl/taverne-license

Take down policy

If you believe that this document breaches copyright please contact us at:

repository@maastrichtuniversity.nl

providing details and we will investigate your claim.
}

Copyright and moral rights for the publications made accessible in the public portal are retained by the authors and/or other copyright owners and it is a condition of accessing publications that users recognise and abide by the legal requirements associated with these

- Users may download and print one copy of any publication from the public portal for the purpose of private study or research.

- You may not further distribute the material or use it for any profit-making activity or commercial gain

If the publication is distributed under the terms of Article $25 \mathrm{fa}$ of the Dutch Copyright Act, indicated by the "Taverne" license above, 


\title{
PET imaging of hypoxia using $\left[{ }^{18} \mathrm{~F}\right] \mathrm{HX} 4$ : a phase I trial
}

\author{
Judith van Loon • Marco H. M. Janssen • Michel Öllers • Hugo J. W. L. Aerts • \\ Ludwig Dubois • Monique Hochstenbag • Anne-Marie C. Dingemans • Roy Lalisang • \\ Boudewijn Brans • Bert Windhorst • Guus A. van Dongen • Hartmuth Kolb • \\ James Zhang • Dirk De Ruysscher • Philippe Lambin
}

Received: 3 December 2009 / Accepted: 24 February 2010/Published online: 6 April 2010

(C) Springer-Verlag 2010

\begin{abstract}
Background and purpose Noninvasive PET imaging of tumour hypoxia could help in the selection of those patients who could benefit from chemotherapy or radiation with specific antihypoxic treatments such as bioreductive drugs or hypoxic radiosensitizers. In this phase I trial, we aimed to determine the toxicity of $\left[{ }^{18} \mathrm{~F}\right] \mathrm{HX} 4$, a member of the 2 nitroimidazole family, at different dose levels. The secondary aim was to analyse image quality related to the HX4 dose and the timing of imaging.

Methods Patients with a histologically proven solid cancer without curative treatment options were eligible for this study. A study design with two dose steps was used in which a single dose of a maximum of $222 \mathrm{MBq}$ (step 1) or $444 \mathrm{MBq}$ (step 2) $\left[{ }^{18} \mathrm{~F}\right] \mathrm{HX} 4$ was injected. Toxicity was scored on day 0 and on days 3 and 7 after injection, according to the CTCAE 3.0
\end{abstract}

J. van Loon $(\bowtie) \cdot$ M. H. M. Janssen • M. Öllers •

H. J. W. L. Aerts $\cdot$ L. Dubois $\cdot$ D. De Ruysscher $\cdot$ P. Lambin

Department of Radiation Oncology (Maastro Clinic),

GROW - School of Oncology and Developmental Biology,

Maastricht University Medical Centre,

Dr. Tanslaan 12,

6229 ET Maastricht, The Netherlands

e-mail: Judith.vanloon@maastro.nl

M. Hochstenbag · A.-M. C. Dingemans

Department of Pulmonology,

Maastricht University Medical Centre,

Maastricht, The Netherlands

R. Lalisang

Department of Medical Oncology,

Maastricht University Medical Centre,

Maastricht, The Netherlands scoring system. PET/CT images of the largest tumour site were acquired 30, 60 and 120 min after injection.

Results Six patients with stage IV carcinoma were included, four with non-small-cell lung carcinoma, one with thymus carcinoma, and one with colon carcinoma. No toxicity was observed in any of the patients at either dose level. The median tumour to muscle ratio $120 \mathrm{~min}$ after injection was 1.40 (range $0.63-1.98$ ).

Conclusion The findings of this study showed that $\left[{ }^{18} \mathrm{~F}\right]$ HX4 PET imaging for the detection of hypoxia is not associated with any toxicity. Imaging was successful; however, future trials are needed to determine the optimal image parameters.

Keywords Hypoxia $\cdot$ PET $\cdot{ }^{18} \mathrm{~F}-\mathrm{HX} 4 \cdot 2$-Nitroimidazoles . Phase I trial

\section{B. Brans}

Department of Nuclear Medicine,

Maastricht University Medical Centre,

Maastricht, The Netherlands

B. Windhorst · G. A. van Dongen

Department of Nuclear Medicine and PET research,

VU University Medical Centre,

Amsterdam, The Netherlands

G. A. van Dongen

Department of Otolaryngology/Head and Neck Surgery,

VU University Medical Centre,

Amsterdam, The Netherlands

H. Kolb · J. Zhang

Siemens Molecular Imaging,

North Wales, PA, USA 


\section{Introduction}

Tumour hypoxia is an important marker of cancer prognosis, being associated with aggressive growth, metastasis, and resistance to anticancer therapy [1]. Noninvasive PET imaging with hypoxia-specific 2-nitroimidazoles has the ability to quantify tumour hypoxia and could help in the selection of those patients who could benefit from chemotherapy or radiation with specific antihypoxic treatments such as bioreductive drugs or hypoxic radiosensitizers [2]. Furthermore, in contrast to invasive electrode measurements, PET imaging provides the opportunity to display the spatial distribution of hypoxia, which is essential for its integration with radiation dose distribution. $\left[{ }^{18} \mathrm{~F}\right]$ Fluoromisonidazole $\left(\left[{ }^{18} \mathrm{~F}\right] \mathrm{FMISO}\right)$ is the first radiolabelled 2-nitroimidazole derivative proposed for hypoxia imaging with PET [3, 4]. The relatively low uptake of $\left[{ }^{18} \mathrm{~F}\right] \mathrm{FMISO}$ observed in hypoxic lesions coupled with its slow clearance from normoxic tissue, however, limits the clinical potential of this agent [5]. A number of other ${ }^{18} \mathrm{~F}$-labelled nitroimidazole derivatives have been identified, investigated and reported to overcome these problems $[6,7]$.

The 2-nitroimidazole nucleoside analogue, $3-\left[{ }^{18} \mathrm{~F}\right]$ fluoro2-(4-((2-nitro-1H-imidazol-1-yl)methyl)-1H-1,2,3-triazol-1yl)propan-1-ol $\left(\left[{ }^{18} \mathrm{~F}\right] \mathrm{HX} 4\right)$, was developed as a potential marker and radiosensitizer for hypoxic tumour cells. Because of better water solubility and faster clearance, we expect that $\left[{ }^{18} \mathrm{~F}\right] \mathrm{HX} 4$ has better pharmacokinetic properties than currently used nitroimidazole hypoxia markers such as $\left[{ }^{18} \mathrm{~F}\right] \mathrm{FMISO}$.

In this phase I trial, we aimed to determine the toxicity of $\left[{ }^{18} \mathrm{~F}\right] \mathrm{HX} 4$ at different dose levels, with the secondary aim of analysing image quality in relation to the HX4 dose and timing of imaging.

\section{Methods}

Patient inclusion

Patients with a histologically or cytologically confirmed stage IV solid cancer at any site, primary or secondary, without curative treatment options, were eligible. Patients were required to have a WHO performance status of 0 to 1 , normal white blood cell count and differential, normal platelet count and no anaemia requiring blood transfusion or erythropoietin. Additional eligibility criteria were adequate hepatic function, adequate renal function (calculated creatinine clearance at least $60 \mathrm{ml} / \mathrm{min}$ ), no administration of ${ }^{18} \mathrm{~F}$ in the previous $24 \mathrm{~h}$, and a minimum age of 18 years. Patients with a recent $(<3$ months) myocardial infarction, uncontrolled infectious disease, pregnancy, or concurrent treatment with anticancer agents or radiotherapy were excluded.

Approval for the study protocol (NCT00690053) was obtained from the medical ethics committee and the radiation safety committee. All patients gave written informed consent.

Study design

A study design with two dose steps was used (Fig. 1). In step 1 , a single dose of up to $222 \mathrm{MBq}\left[{ }^{18} \mathrm{~F}\right] \mathrm{HX} 4$ was injected, and in step 2 a single dose of up to $444 \mathrm{MBq}$ was injected. Six patients were included, three in each dose step. If in any patient a toxicity of grade 2 or more was observed, three more patients were included in this dose step. If another toxicity of grade 2 or more occurred in one or more of three patients, the study would be stopped. If no more than one of six patients experienced grade 2 toxicity, the step was considered safe.

Synthesis of $\left[{ }^{18} \mathrm{~F}\right] \mathrm{HX} 4$

$\left[{ }^{18} \mathrm{~F}\right] \mathrm{HX} 4$ was synthesized from the HX4 precursor in a two-step process (Fig. 2). The product obtained was purified and formulated into a sterile and pyrogen-free solution suitable for use in humans. The radiochemical purity was required to be higher than $95 \%$ in every batch. The specific radioactivity of $\left[{ }^{18} \mathrm{~F}\right] \mathrm{HX} 4$ exceeded $14.8 \mathrm{MBq} /$ $\mu \mathrm{mol}$. The radiopharmaceutical was produced at the government-licensed GMP-compliant (EMEA Eudralex 4) radiopharmaceutical production facility of the Department of Nuclear Medicine and PET Research of the VU University Medical Centre (license number 108897F).
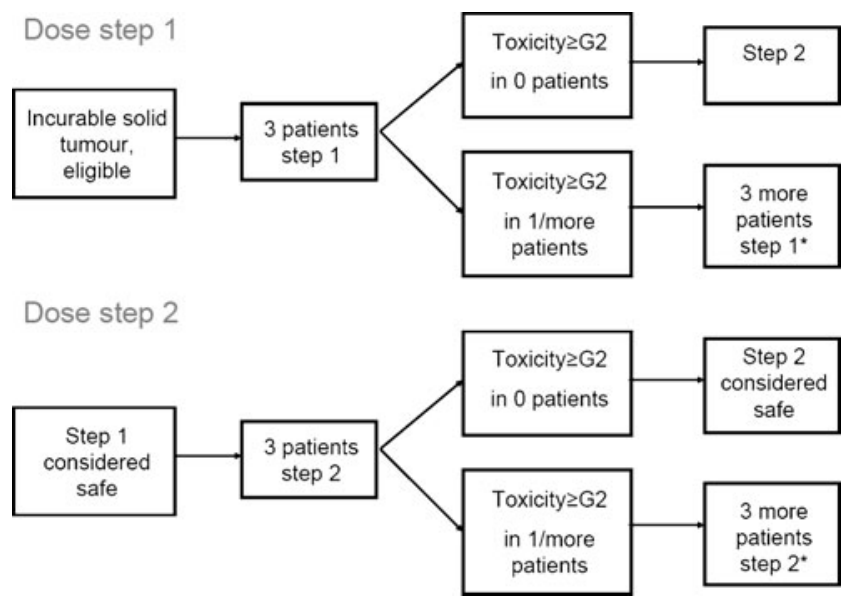

Fig. 1 Flow chart of the study. Asterisks If toxicity of grade 2 or more was observed in none of these patients, the step was considered safe; if toxicity of grade 2 or more was observed in one or more patients, the study was stopped 


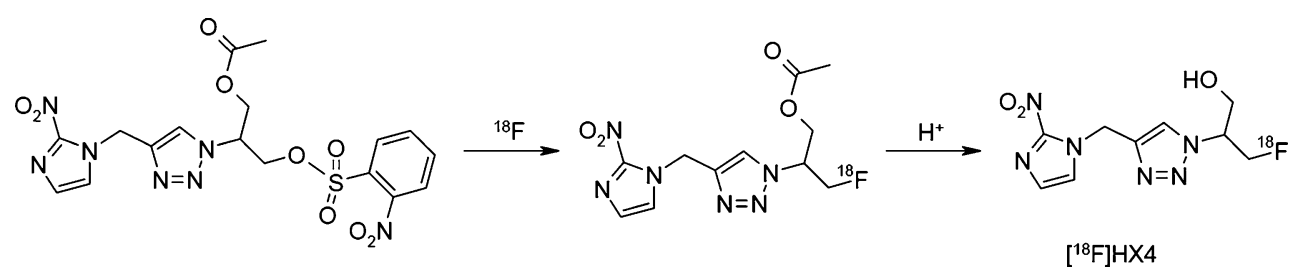

Fig. 2 Synthesis of $\left[{ }^{18} \mathrm{~F}\right] \mathrm{HX} 4$. The precursor was supplied by Siemens Molecular Imaging (Erlangen, Germany). The first step is a nucleophilic substitution of radioactive fluorine (in the form of ${ }^{18} \mathrm{~F}$ )

\section{PET/CT imaging}

PET/CT images of the largest tumour site were acquired 30, 60 and 120 min after injection. Imaging at later time-points after injection was deliberately avoided to minimize the burden of the study in these patients with advanced disease. Images were acquired with the patient in the supine position. CT and PET images were automatically registered based on mutual information and were subsequently fused using dedicated software (TrueD, version VC50; Siemens Medical, Erlangen, Germany).

The tumour was delineated on the CT scan by the same observer (J.v.L.). The location of the $\left[{ }^{18} \mathrm{~F}\right] \mathrm{HX} 4$ uptake and the $\mathrm{SUV}_{\max }$ (maximal standardized uptake value) were determined within the delineated tumour using a gradientbased method which was implemented in the software. Tumour to muscle ratios (TMR) for $\left[{ }^{18} \mathrm{~F}\right] \mathrm{HX} 4$ uptake were calculated at all time-points by dividing the tumour $\mathrm{SUV}_{\text {max }}$ by the skeletal muscle $\mathrm{SUV}_{\max }$. The skeletal muscle $\mathrm{SUV}_{\text {max }}$ was determined by calculating the average $\mathrm{SUV}_{\text {max }}$ in two circular regions of interest drawn in the paraspinal muscles.

In patients in whom an $\left[{ }^{18} \mathrm{~F}\right] \mathrm{FDG}-\mathrm{PET}$ scan was performed for diagnostic purposes during the week before or after the $\left[{ }^{18} \mathrm{~F}\right] \mathrm{HX} 4$ scan, uptakes of $\left[{ }^{18} \mathrm{~F}\right] \mathrm{FDG}$ and $\left[{ }^{18} \mathrm{~F}\right]$ HX4 were compared. The location of the $\left[{ }^{18} \mathrm{~F}\right] \mathrm{FDG}$ uptake was determined using automated SUV-thresholding with the threshold depending on the tumour-to-background signal ratio method [8].

\section{Toxicity scoring}

Toxicity was scored on day 0 and on days 3 and 7 after injection, according to the CTCAE (Common Terminology Criteria for Adverse Events) version 3.0 scoring system. Blood was sampled before injection and at each control point, and the tests included haematology and kidney and liver function. Due to the relatively short physical half-life of ${ }^{18} \mathrm{~F}$ (110 min) and biological half-life of HX4 (less than $3 \mathrm{~h}$ ), after 1 day the radioactivity of both the drug and its metabolites have disappeared and no additional toxicity from the radiation is expected. onto the precursor material, yielding the fluorinated intermediate which is then hydrolysed to obtain the active drug product

The time-line for each patient entering the study is illustrated in Fig. 3.

\section{Results}

Patient characteristics

Six patients, with a median age of 63 years (range 5468 years), were included. The patient characteristics are shown in Table 1. All patients had a stage IV carcinoma: four had a non-small-cell lung carcinoma, one had a thymus carcinoma and one patient a colon carcinoma. Three patients had stage IV disease at primary diagnosis, while the others had developed metastases after therapy with curative intent. All patients had previously undergone anticancer therapy. Two patients were unable to undergo

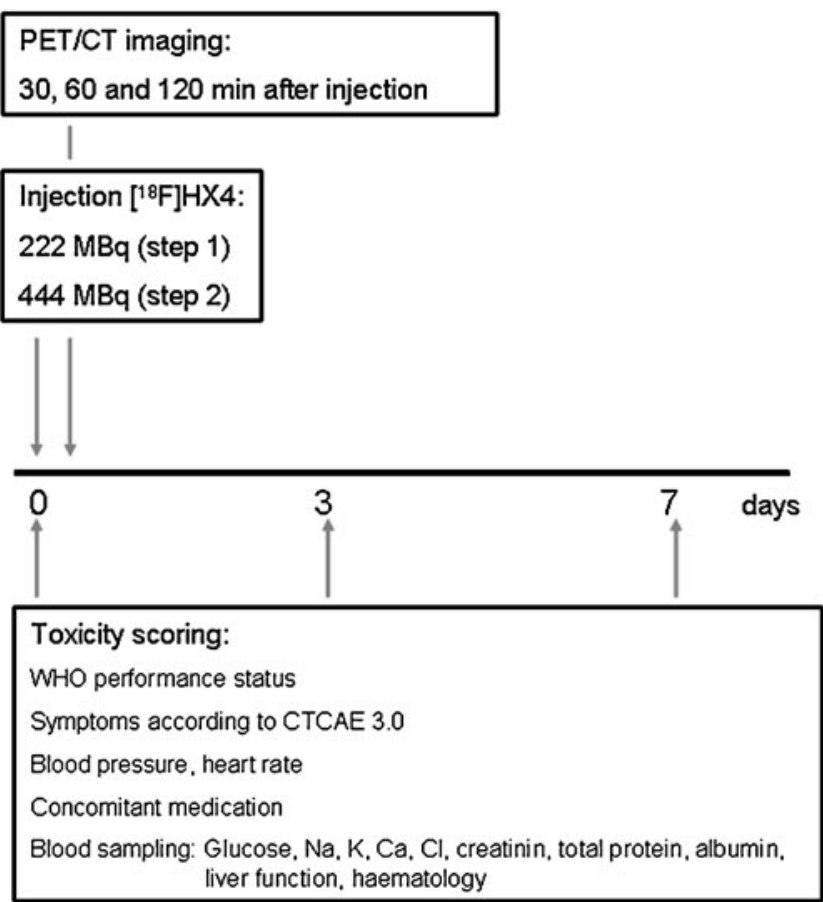

Fig. 3 Time-line of the study 
Table 1 Patient characteristics

\begin{tabular}{|c|c|c|c|c|c|c|c|c|}
\hline \multirow[t]{2}{*}{ Patient } & \multirow{2}{*}{$\begin{array}{l}\text { Age } \\
\text { (years) }\end{array}$} & \multirow[t]{2}{*}{ Sex } & \multirow{2}{*}{$\begin{array}{l}\text { Height } \\
(\mathrm{m})\end{array}$} & \multirow{2}{*}{$\begin{array}{l}\text { Weight } \\
(\mathrm{kg})\end{array}$} & \multirow{2}{*}{$\begin{array}{l}\text { WHO performance } \\
\text { status }\end{array}$} & \multicolumn{2}{|c|}{ Primary tumour } & \multirow[t]{2}{*}{ Prior therapy } \\
\hline & & & & & & Site & Histology & \\
\hline 1 & 67 & $\mathrm{~F}$ & 1.58 & 58 & 1 & Lung & Adenocarcinoma & $\begin{array}{l}\text { Chemotherapy, radiotherapy } \\
\text { brain }\end{array}$ \\
\hline 2 & 54 & $\mathrm{~F}$ & 1.76 & 64 & 0 & Lung & Adenocarcinoma & Chemotherapy \\
\hline 3 & 58 & M & 1.79 & 82 & 0 & Thymus & Carcinoid & Surgery, radiotherapy \\
\hline 4 & 62 & M & 1.90 & 80 & 1 & Lung & Adenocarcinoma & $\begin{array}{l}\text { Surgery, chemotherapy, } \\
\text { radiotherapy }\end{array}$ \\
\hline 5 & 63 & $\mathrm{~F}$ & 1.70 & 70 & 1 & Lung & $\begin{array}{l}\text { Squamous cell } \\
\text { carcinoma }\end{array}$ & Surgery, chemotherapy \\
\hline 6 & 68 & M & 1.68 & 80 & 0 & Colon & Adenocarcinoma & Surgery, chemotherapy \\
\hline
\end{tabular}

the last scan at 120 min after injection due to pain (not drug-related).

\section{Toxicity}

Results of the toxicity scoring are shown in Table 2. No toxicity according to the CTCAE 3.0 criteria was observed at any time-point in the first three patients included in dose step 1. Hence, it was considered safe to continue with dose step 2. Again, no toxicity was observed in any of the three patients. One patient reported mild transient headache (grade 1) the day after the $\left[{ }^{18} \mathrm{~F}\right] \mathrm{HX} 4$ injection, which was considered unlikely to be related to the injection.

Image analysis

Images in two patients at $120 \mathrm{~min}$ after injection are presented in Fig. 4. They show a heterogeneous uptake of $\left[{ }^{18} \mathrm{~F}\right] \mathrm{HX} 4$ throughout the tumour. The median TMR at 30, 60 and 120 min after injection was 1.17 (range 0.20-1.83), 1.25 (range $0.25-1.67$ ) and 1.40 (range 0.63-1.98). In two of four patients in whom images were available at $120 \mathrm{~min}$ after injection a considerable increase was seen in the TMR compared to $60 \mathrm{~min}$ after injection.

In three patients a $\left[{ }^{18} \mathrm{~F}\right] \mathrm{FDG}-\mathrm{PET}$ scan performed during the week before or after the $\left[{ }^{18} \mathrm{~F}\right] \mathrm{HX} 4-\mathrm{PET}$ scan was available. In these three patients, there was a good correlation between the uptakes of $\left[{ }^{18} \mathrm{~F}\right] \mathrm{FDG}$ and $\left[{ }^{18} \mathrm{~F}\right]$ HX4 as shown in Fig. 5.

\section{Discussion}

Preclinical experience gained with $\left[{ }^{18} \mathrm{~F}\right] \mathrm{HX} 4$ and unlabelled HX4 did not indicate any adverse events at the dose levels used in these exploratory trials. The current phase I trial confirmed these preclinical data, with no toxicity according to the CTCAE 3.0 criteria observed in any of the patients. The time curves of the TMR showed a large divergence between the patients. In two patients, a substantial increase in TMR was seen in the second hour after injection, indicating that the optimal TMR for imaging may be at later time

Table 2 Toxicity scoring. Toxicity was scored before study entry (baseline) and on days 0,3 and 7 of the study. The blood test results were compared with those at baseline and evaluated by the physician

\begin{tabular}{|c|c|c|c|c|c|c|c|}
\hline \multirow[t]{2}{*}{ Patient } & \multirow[t]{2}{*}{ Injected activity (MBq) } & \multirow[t]{2}{*}{ Vital signs $^{\mathrm{a}}$} & \multicolumn{4}{|c|}{ Toxicity scoring $^{\mathrm{b}}$} & \multirow[t]{2}{*}{ Medication $^{\mathrm{a}}$} \\
\hline & & & Haematology & Liver function & Kidney function & Symptoms & \\
\hline 1 & 222 & 0 & 0 & 0 & 0 & 0 & 0 \\
\hline 2 & 222 & 0 & 0 & 0 & 0 & 0 & 0 \\
\hline 3 & 222 & 0 & 0 & 0 & 0 & 0 & 0 \\
\hline 4 & 444 & 0 & 0 & 0 & 0 & $1^{\mathrm{c}}$ & 0 \\
\hline 5 & 444 & 0 & 0 & 0 & 0 & 0 & 0 \\
\hline 6 & 444 & 0 & 0 & 0 & 0 & 0 & 0 \\
\hline
\end{tabular}

a Every change in vital signs or medication compared to the baseline values was scored " 0 " indicating no change.

${ }^{\mathrm{b}}$ Grade according to CTCAE version 3.0.

${ }^{\mathrm{c}}$ Mild headache, not related to the ${ }^{18} \mathrm{~F}[\mathrm{HX} 4]$ administration. 
Fig. $4\left[{ }^{18} \mathrm{~F}\right] \mathrm{HX} 4$ images in two patients. a, b Patient 4 (TMR 1.35): a coronal image, $\mathbf{b}$ transverse image. c, d Patient 5 (TMR 1.98): c coronal image, $\mathbf{d}$ transverse image
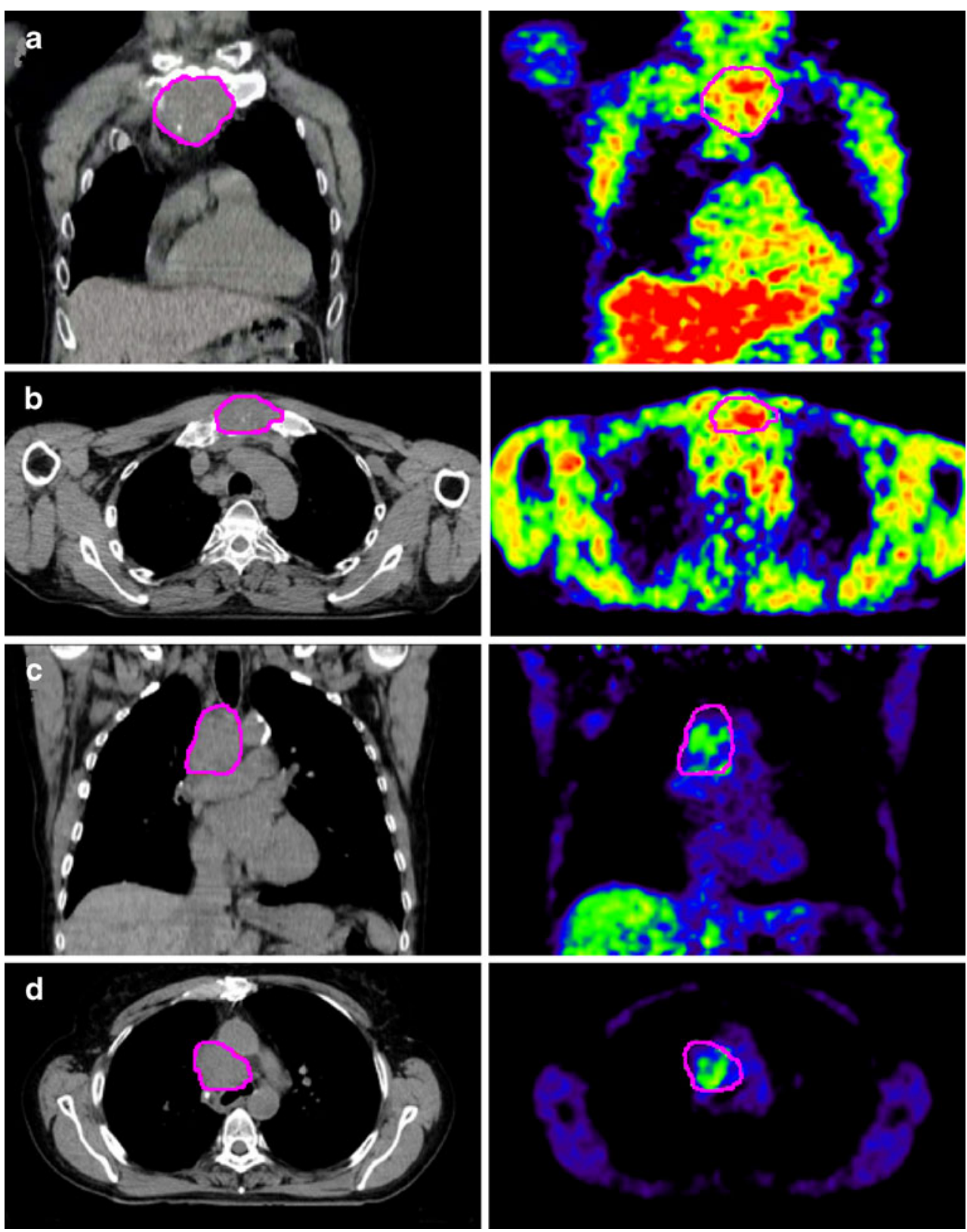

points. In the three patients in whom an $\left[{ }^{18} \mathrm{~F}\right] \mathrm{FDG}$-PET scan was available, a good correlation was found between the hypoxic areas imaged with HX4 and the areas of high FDG uptake. This is consistent with the often observed relationship between tumour hypoxia and FDG uptake $[9,10]$.

From the imaging perspective, there were some limitations inherent in the study design. Firstly, the imaging was limited to $120 \mathrm{~min}$ after injection. This time horizon was chosen to limit the burden on the patients, who were all suffering from end-stage disease. Future studies, with the final aim of adapting treatment according to hypoxia, will be performed in patients with earlier stage disease, in whom imaging at later time points would be acceptable. Secondly, only static PET imaging was performed. Hence, no correction could be made for heterogeneity in tumour perfusion. With kinetic imaging, tumour perfusion can be measured, thereby offering the opportunity to differentiate between differences in delivery of $\left[{ }^{18} \mathrm{~F}\right] \mathrm{HX} 4$ and differences in $p \mathrm{O}_{2}$ within the same tumour [4]. Finally, in order to allow radiotherapy dose distribution within the tumour on the basis of hypoxia, the stability of hypoxic regions within the tumour before and at different time-points during chemo- and radiotherapy should be assessed.

\section{Conclusion}

The results presented show that $\left[{ }^{18} \mathrm{~F}\right] \mathrm{HX} 4$ PET imaging was not associated with any toxicity. Future trials are 
Fig. 5 Correlation between the uptakes of $\left[{ }^{18} \mathrm{~F}\right] \mathrm{HX} 4$ and $\left[{ }^{18} \mathrm{~F}\right]$ FDG (patient 5). FDG uptake in the tumour was delineated using automated SUV thresholding depending on the tumour-tobackground signal ratio. The HX4-positive regions in the tumour were delineated using gradient-based image analysis. a, b ${ }^{18}$ FDG-PET/CT images: a axial, b coronal. c, d $\left[{ }^{18} \mathrm{~F}\right] \mathrm{HX} 4-$ PET/CT images: c axial, d coronal
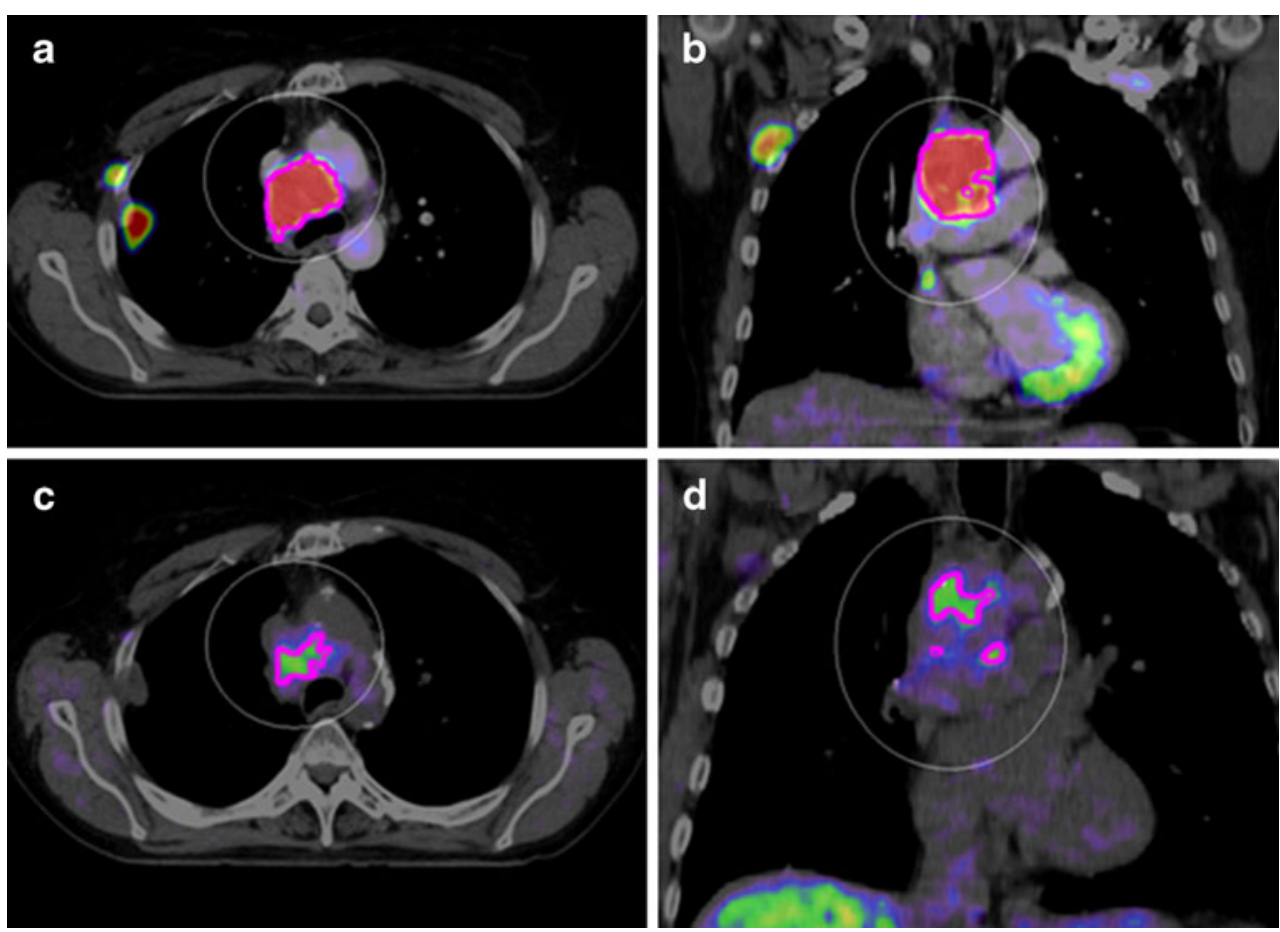

needed to determine optimal imaging conditions, with the final aim of developing adaptive treatment strategies based on $\left[{ }^{18} \mathrm{~F}\right] \mathrm{HX} 4$-imaged hypoxia.

Conflicts of interest The unlabelled HX4 and its precursor were kindly provided by Siemens Molecular Imaging.

The authors acknowledge financial support from the Dutch Cancer Society (KWF fellowship granted to H.J.W.L.A.).

\section{References}

1. Ruan K, Song G, Ouyang G. Role of hypoxia in the hallmarks of human cancer. J Cell Biochem 2009;107:1053-62

2. Wouters BG, Weppler SA, Koritzinsky M, Landuyt W, Nuyts S, Theys $\mathrm{J}$, et al. Hypoxia as a target for combined modality treatments. Eur J Cancer 2002;38:240-57.

3. Rasey JS, Grunbaum Z, Magee S, Nelson NJ, Olive PL, Durand $\mathrm{RE}$, et al. Characterization of radiolabeled fluoromisonidazole as a probe for hypoxic cells. Radiat Res 1987;111:292-304.
4. Thorwarth D, Eschmann SM, Paulsen F, Alber M. A kinetic model for dynamic [18F]-Fmiso PET data to analyse tumour hypoxia. Phys Med Biol 2005;50:2209-24.

5. Nunn A, Linder K, Strauss HW. Nitroimidazoles and imaging hypoxia. Eur J Nucl Med 1995;22:265-80.

6. Krohn KA, Link JM, Mason RP. Molecular imaging of hypoxia. J Nucl Med 2008;49 Suppl 2:129S-48S.

7. Piert M, Machulla HJ, Picchio M, Reischl G, Ziegler S, Kumar P, et al. Hypoxia-specific tumor imaging with $18 \mathrm{~F}$-fluoroazomycin arabinoside. J Nucl Med 2005;46:106-13.

8. Ollers M, Bosmans G, van Baardwijk A, Dekker A, Lambin P, Teule $\mathrm{J}$, et al. The integration of PET-CT scans from different hospitals into radiotherapy treatment planning. Radiother Oncol 2008;87:142-6.

9. Dierckx RA, Van de Wiele C. FDG uptake, a surrogate of tumour hypoxia? Eur J Nucl Med Mol Imaging 2008;35:1544-9.

10. van Baardwijk A, Dooms C, van Suylen RJ, Verbeken E, Hochstenbag M, Dehing-Oberije $\mathrm{C}$, et al. The maximum uptake of (18)F-deoxyglucose on positron emission tomography scan correlates with survival, hypoxia inducible factor-1alpha and GLUT-1 in non-small cell lung cancer. Eur $\mathrm{J}$ Cancer 2007;43:1392-8. 